\title{
Study on the Listing System of Financial Derivatives
}

\author{
Jianan Wei ${ }^{1}$ \\ ${ }^{1}$ Wuhan University, Wuhan, Hubei, 430072
}

KEYWORDS: Financial Derivatives; Listing System; Economy Market

\begin{abstract}
Derivatives listing is becoming one of the main trends in the global market competition and evolution. China's financial derivatives market is increasingly becoming the focus of global concern, since the Shanghai and Shenzhen 300 stock index futures market, there are many overseas exchanges proposed plans listed China concept derivatives. This paper analyzes the main characteristics of forms of financial derivatives and the development of cross-listing of proposed reform of financial derivatives listed mechanisms.
\end{abstract}

\section{Introduction}

In recent years, the increase in financial derivatives exchange market is significantly higher than the OTC market, to focus on the trend Exchange derivatives trading occurs. Financial futures, for example, the exchange market trading volume of futures market shares more than $85 \%$ and far exceeds the size of the spot market. In the world's top 20 futures contracts, there are 18 financial futures contracts. Financial futures, options generated as good as the third revolution in the futures market, and stock options, forward transactions, currency and interest rate swaps and other investment vehicles jointly promote the development of modern risk management industry. According to statistics, in the financial derivatives market, the largest open interest forward transactions, accounting for $42 \%$ of the total open interest, swaps, futures and options, respectively, $27 \%, 18 \%$ and $13 \%$ ratio.

After the change with the rapid development of electronic network technology, financial deregulation and globalization of financial environment, in particular on the exchange have been implemented to Companies, the world's exchanges are to expand through various fields, competition and cooperation in different ways business, expand its influence, to seek their own interests. Wherein the cross-listing of financial derivatives 1 become a major trend of development of market competition and the evolution of a number of overseas exchanges on China's futures market has a strong interest. Learn how and why the global exchange of cross-listing, objective analysis of the pros and cons of influence, and actively explore appropriate measures for the fledgling China's financial futures market, long-term healthy development of the reform and opening up and innovation of China's capital market development, has important practical significance.

\section{Situation Innovation Mode of Financial derivatives}

In Listing System futures for example, from a global perspective, the current futures listed species exist approval system, registration system and approval system of the three modes. Developed countries are to take a more registration system. In the United States developed financial derivatives, 5 Commodity Futures Modernization Act of 2000, which entered into force December 16 (CFMA), removed many restrictions 56 Commodity Exchange Act and CFTC, to promote a more flexible 
approach, greatly expanded the regulated exchanges to innovate free space, so that by the CFTC regulated futures exchanges in the self-certification program, based on the CFTC without prior approval to market for new products and develop new rules. Thus, the exchange can be more timely introduction of new products and the amendment to increase the ability to compete globally Exchange; Japan new varieties in the futures market, the past has been to implement a useful theory, which must prove that new varieties traded beneficial to society and then reported to the approval of the Minister in charge of the respective futures. After 1990, a useful theory to sound theory that exchanges can be based on the development needs of the test market for new varieties, after two years of trial operation proved no harm to society, and reported to the Minister in charge of approval of the futures, then officially traded. Itself is due to the government agencies, can develop their own products, without going through the government approval, the listing of new varieties mechanism in full accordance with market mechanism, is determined by the exchanges themselves. Provisional Regulations on Administration of Futures Trading 5 from September 1, 1999 for the purposes of Article 17 6, / futures market, suspend, cancel or resume futures varieties, 0 shall be approved by the China Securities Regulatory Commission. Thus, the law gives China Securities Regulatory Commission approval of the qualifications and powers listed futures variety, our futures to be listed by the approval of the SFC and the Stock Exchange shall not be altered or adjusted futures contracts have been approved. In addition, although 56 Provisional Regulations on Administration of Futures Trading Commission will grant China listed futures variety of power, but in practice, it is also required to seek the relevant ministries and local governments by the China Securities Regulatory Commission after opinion by the State Council instructed the last State Council for approval. Seen in this light, our policy is a strict examination and approval system.

This harsh, the financial derivatives innovation model under the guidance of the State Council and is formed in a specific historical stage, with historical inevitability. In the case of the market itself and the legal system environment has undergone great changes in the level of financial derivatives innovation model under the State Council executive-led government has been unable to meet the future needs of the market, in need of reform.

\section{Listing Location of Financial Futures Market Supervision Mode}

First, the financial futures market and futures market supervision Listing mode now, the financial futures market place there are three modes: first, in the commodity futures market listed financial futures, such as the Chicago Mercantile Exchange, Chicago Mercantile Exchange, Korea Exchange, HKEx and the like. Second, while the stock market and futures market trading financial futures, formed a good momentum of the development of competition, such as the Tokyo Stock Exchange, Osaka Securities Exchange and the Tokyo International Financial Futures Exchange and the like. Third, aside Mercantile Exchange and set up a separate financial futures exchange, such as the Singapore International Monetary Exchange, the London International Financial Futures and Options Exchange. I believe that a country's financial futures select a location is not accidental, but rather the degree of a country's financial market development, financial regulatory system, the traditional trading habits are closely related.

Authorize the US futures exchange listing mode. In 1974 the US Congress on the basis of the original 5 Commodity Exchange Act 6, through a rigorous system 56 Commodities Trading Commission Act, established the National CFTC (Commodity Futures Trading Commission, CFTC), the formation of CFTC regulation and Futures Exchange futures, stock exchange and Securities and exchange Commission regulation of securities products, the existing division of labor but also the regulatory landscape for cooperation. In 1982, due to the contention Financial Futures 
and Options jurisdiction of the Commission and of monitoring will occur, the United States Congress to quell conflict of interest, clearly CFTC oversees futures and options trading; SEC is responsible for the spot stock options, stock index stock option regulatory and single stock options. Visible, clear and practices jurisdiction of the Securities and Futures Market classification management system, and the right to determine the custody of listed financial futures attribution Futures and Commodity Futures Trading Commission. In addition, early in the Korea Stock Exchange stock index futures, the futures market after the establishment soon pass legislation to force the transfer of stock index futures to the futures market. The result of this positive market intervention and appropriate institutional arrangements are: South Korea Kospi200 index futures and options trading volume topped the global list, the most dynamic futures market. Hong Kong futures market is somewhat similar to the SFC in Hong Kong under the unified arrangements of March 2000, the Hong Kong Stock Exchange, Hong Kong Futures Exchange and the Hong Kong Securities Clearing Company Limited merged transactions with Clearing AG and achieve market, but retained derivatives trading securities and futures exchanges operate separately mechanisms, financial futures and options, are still in the futures exchanges. ${ }^{1}$

Japan Securities Exchange also listed mode. Japan and the US, there is no dedicated centralized futures regulatory agencies, adoption / 0 provinces centralized management system decentralized regulation of futures markets: the agricultural futures market managed by the Ministry of Agriculture, the transaction is limited to grain varieties, such as Tokyo Grain Exchange; industrial futures market managed by the Ministry of economy, only listed industrial products.

Singapore's financial futures markets as an important part of the emerging markets in the international financial markets, plays a decisive role. In order to create a financial pricing center in Asia, Europe, North America, sharing district, financial derivatives become the government's economic development policies preferable. MAS is outside the stock exchange, the reorganization of the Gold Exchange, the founder of International Financial Exchange in 1984. Since there is no exclusive right to financial derivatives, Singapore ahead of the introduction of Japan's Nikkei 225 index futures, and subsequently opened to foreign direct numerous as the underlying index and interest rates, equity derivatives in 1986. Government of Singapore to promote legislation to reinvent the wheel Form International Financial Exchange practices has been a huge success, SIMEX has become the world's largest Eurodollar futures market, the number of awards won the world's best international exchanges.

\section{The Specific Construction of Financial Derivative Listing}

In particular build, since its financial derivatives whether the issue areas, the issue can be divided into classes of derivatives and derivative contracts class. Thus specific mechanisms to build its listing, we should distinguish between the issue financial derivative contracts and financial derivatives to be.

In terms of listed securities derivatives, and 6 of the Securities Act of 5 new shares, corporate bonds by the Exchange approved, but has not changed the practice of statutory listing requirements, are not radical institutional change, the reason, mainly equities, corporate bonds is the most important capital securities listing requirements of legal fait accompli for many years, its listing regime change by thinking and special market environment constraints, involving corporate law and securities law harmonization of legislation, difficult step. For securities derivatives, this problem does not exist, it should provide the conditions listed by the Exchange. The main reason is that different types of securities derivatives, the law can not be given by one of the conditions listed previously specified. In the overseas market, without exception, by the provisions of securities 
derivatives market place listing requirements. Moreover, the current law has not been too difficult to define the conditions for listing securities derivatives in the short term, by the provisions of the Stock Exchange listing requirements, without changing the existing system. In addition, securities derivatives trading venues should be targeted at the stock exchange, requiring all securities derivatives with its base at the same exchange-traded securities, securities in favor of the formation of the spot market and derivatives market mutual promotion and common development of a good situation meet the inherent requirements of securities derivatives market is conducive to exchanges of securities derivatives and underlying securities to implement effective regulation, market participants will help reduce costs and operating costs of the market. Financial derivatives contract issue does not exist the problem, and thus does not issue its approval or approval of the problem, and is generally designed by the Exchange by way of standard contract will be. The development and demonstration is generally under the auspices and coordination of exchanges, each of the financial institutions (including the Exchange itself) as required by the professional organizations to make their own experts to conduct feasibility studies. This is the financial derivatives market access for preparatory work, which should include: the development of financial derivatives feasibility analysis, economists from the theory and practice of jurists and relevant practice participants demonstrated an expert team feasibility report is within the prescribed time for the submission of financial institutions to conduct derivatives business, the business plan or the industry trade show plans to conduct feasibility studies and ultimately the formation of development feasibility report. The report will be an important basis for the development of a new regulatory body for financial derivatives traded whether ultimately be addressed by the regulatory authorities of the financial derivatives traded scrutiny intended to decide whether to approve.

\section{Conclusion}

Financial derivatives listed mechanisms, focus on related products permit system design. Financial Futures Exchange introduced futures, securities law is bound to broaden the bank funds into the market channel, breaking the securities and futures market hedge, the implementation of cash settlement, guide state-owned enterprises to participate in an orderly market and achieve market listing mechanism, the pilot of the Exchange Company of the system is the prerequisite and guarantee. It is foreseeable that in the mixed impact of the wave, the new system under the Securities Act of innovative securities and futures boundaries blur the background, China's commodity futures exchange listed financial derivatives, financial futures exchange re-launch is still an irresistible trend .

\section{Reference:}

[1] Orlitzky, M., Schmidt, F.L \& Rynes, S L. Corporate Social and Finacial Performance: A Meta-analysis [J]. Organization Studies, 2003,24 (3): 403-441.

[2] Orlitzky, M., Swanson, D. L. Value attunement: Toward a theoryof socially responsible executive decision making [J]. Australian Journal ofManagement, 2002, 27 (Special Issue): 119-128.

[3] Parker, L..Polemical themes in social accounting: scenario forstandard setting, in Niemark, M., Merino, B. and Tinker, T [M] .Advances in Public Interest Accounting Vol.1,. (Eds.) greenwich: JAI. Press Inc, 1986: 67-97.

[4] Pistor, Katharina and Chenggang Xu.Governing Stock Markets in Transition Economis: Lessons from China [J]. American Law and Economics Review, 2005,7: 184-210. 